\title{
ARTICLE A Predictive Investment Scheme for Dhaka Stock Exchange
}

\author{
A. H. M. Kamal (D) Md. Kaysar Abdullah \\ Jatiya Kabi Kazi Nazrul Islam University, Bangladesh
}

Received: 30 December 2021; Accepted: 18 January 2022; Published: 19 January 2022

\begin{abstract}
Stock market plays a vital role in industrial development of a country. People invest money to make profit from market. Inexperience investors cannot yield profit due to their weak predictions. This research tries to understand the nature of those investors and their demands. Most investors first analyze the prospect of companies based on rate of up-down in prices of share, given bonus, companies' goodwill, temptation by others, etc.. This research presents a good prediction methodology for the stock market investors and thus, will help them to achieve a profit. It will improve the stability of a market.
\end{abstract}

Keywords: Stock exchange market, Trade, Electronic trading, Share, Dividend, DSE, Prediction

\section{Introduction}

Business is regarded as the key to prosperity. Doing business requires money as well as time to be invested. There are many people who have idle money in their hand, but feel risk in investing in business. Again, a good number of them do not have enough time to spend their money in a business. They, instead, look for a place where they could invest their money sparing a little time from their busy schedule. Stock market could be a suitable place for such people.

A stock exchange is like an institution, organization or association which presents a virtual market for trading financial instruments, e.g., stocks, bonds ${ }^{[1]}$. Almost all countries have their own market for trading shares.
Though most of them are open to their country people ${ }^{[1-3]}$, several of them are exposed to any investor in the world ${ }^{[4]}$. Modern stock exchanges, like Dhaka stock exchange (DSE) ${ }^{[1]}$, the New York stock exchange ${ }^{[2]}$, have their own trading floor from where they work. Electronic trading system makes the market attractive to all. Electronic trading is a very easy system to trade for buying or selling share. Moreover, it reduces the cost of entry into the market ${ }^{[1,5-8]}$. Like the other markets in the world, DSE allows electronic trading system. DSE has a good platform, i.e., a website, to check last traded price of shares, their dividends, wealth and earning of each company and related historical data of last three years. That platform also allows to place a selling and buying order through online.

*Corresponding Author:

A. H. M. Kamal,

Jatiya Kabi Kazi Nazrul Islam University, Bangladesh;

Email:kamal@jkkniu.edu.bd

DOI: https://doi.org/10.54963/dtra.v1i1.26

Copyright (C) 2022 by the author(s). Published by UK Scientific Publishing Limited. This is an open access article under the Creative Commons Attribution (CC BY) license (https://creativecommons.org/licenses/by/4.0/). 
DSE market is a big place for the investors. It supports electronic trading system. So, it is like a virtual market. As it is open to all, anyone can do trading business staying at home ${ }^{[9-12]}$. Consequently, by the last ten years, per day trading amount ranges from 3000-30000 million Taka, i.e., currency of Bangladesh, and market capital is 68.5 billion US dollar ${ }^{[1]}$. There are about 1.5 million active investors in the market. Therefore, it is a large market place. But many cheat people work to grab the money from the market ${ }^{[13-16]}$. Those people make the market risky, especially for the new investors. If the investors could get a computerized system to analyze the share and the behavior of the market before buying it, that could be a great help for them. The current DSE system does not give any prediction method to estimate the future profitability of a share ${ }^{[17-20]}$. Realizing the issue, we have developed that system for DSE investors. Our system has proposed a good prediction method for the investors of DSE market.

Literature states that AI related algorithms are the mostly used methods that are applied for predicting good share in the stock market ${ }^{[21-24]}$. However, these take time to learn the market. Moreover, it is hard to consider diverse parameters like cash bonus, dividends and earning per share in the learning state whereas bonus and dividend attract investors significantly ${ }^{[25,26]}$. Investor does not understand all issues related to a learning system. They cannot select proper parameters for learning and testing properties of shares. On the other hand, if the investors find a system that works on fewer and easy parameters, e.g., today's price of share, prices of last one month, three month, six month, an year, etc, and if the system is given the ability to predict good investable shares depending on up and down trends of those parameters, the investors will accept it gladly. Considering those issues, we have developed a method of predicting DSE share. It is a new amendment in this field. Though it is not exercised in the stock market of other countries, we believe that it would be a contributory system for those markets as well.

\section{Proposed Prediction Method}

The proposed model works in two steps. First, it acquires data from DSE website. Second, the method applies its prediction policy to estimate the prospect of the share. These two steps are explained in the following.

\subsection{Data Acquisition from DSE Website}

DSE has an organized website which provides various historical data of last three years for all of its registered companies. We designed an interface to read these data from the DSE site. We used python technology to grab these data. We first analyzed the site to find the parameters that held these historical data of DSE. Then, we scraped those data from DSE to our system. We made a database to store those scrapped data. While scrapping, we, first, collected all listed short names of tradable companies from DSE site. Thereafter, we gathered all previous traded information for each of the companies, e.g., total trades in number, traded amount in Taka, todays close price, given cash bonus and/or dividend, maximum and minimum traded values of last three months, six months, one year, two years, three years, etc. We stored all short names of the companies and their related historical data in our database.

DSE site contains two types of values-current values and historical values. The last traded values are considered as current values and these are found in 'current price table' of database of DSE site. Next day, those current values either move to or adjust with historical data according to data pattern by the DSE site. We found these historical data at 'historical info table' of DSE site. We developed two scrapping script to acquire these two types of values. Each day, one scrapping script was allowed to run automatically at a pre-defined time to adjust historical values of our database with the DSE site. Similarly, another scrapping script employed for scrapping today's current prices.

\subsection{Make Prediction Based on Acquired Data}

We made prediction from four different perspectives. These are long term prediction, short term prediction, price sensitive alert, projecting to highly profitable shares.

\subsubsection{Long Term Prediction}

The long term prediction method generates four suggestions for the investors based on its analysis. These are highly profitable, profitable, may be profitable, high risk. The estimation method works as follows.

\section{Highly Profitable}

First, consider two variables $A$ and $B$ as lowest and highest price of a share, respectively, within a target period, e.g., one year. Let $C$ be the today's price of the same share. Considering these, in the system, we computed lowest deviation $L D$ by $L D=C-A$ and highest deviation $H D$ by $H D=B-C$. We, then, calculated the ratio $R$ of the highest deviation and lowest deviation by Equation (1).

$R=\frac{H D}{L D}$ 
Suggestion $=\left\{\begin{array}{l}\text { if } 0 \geq R \leq 0.25 \\ \text { if } 0.25>R \leq 0.50 \\ \text { if } 0.5>R \leq 0.75 \\ \text { if } R>0.75\end{array}\right.$

$\left.\begin{array}{r}\text { highly profitable } \\ \text { profitable } \\ \text { may be profitable } \\ \text { highrisk }\end{array}\right\}$

That $R$ is applied in Equation (2) to get an investment suggestion.

\subsubsection{Short Term Prediction}

Short term prediction is useful for those investors who wish to invest in a share for a short period of time. That type of investors wishes to generate a small profit within a short time. To help these investors, we calculate moving average of prices of last one month of a target share and projected the results as 'may be profitable', 'may not be profitable' and 'moderate'.

If moving average price is less than today's price of a share, we marked it as 'may not be profitable'. In other cases, we apply a threshold to quantize the level as profitable or moderate.

\subsubsection{Price Sensitive Alert}

Price sensitive alert is designed to understand whether the trend of moving average curve of prices of a share is upward or downward for last one month, three months and six months. That estimation is useful for greedy investors.

\section{Price sensitive alert of yesterday}

That feature is designed to help the investor to take a good buying and selling decision. If price of a desired share increases by an amount regarding the price of yesterday, that is closed to $10 \%$, the system then alerts the investor so that the investor can take a decision to sell the current share. The same is done to help in buying share while decreasing a price that is close to $10 \%$.

\subsubsection{Show Highly Profitable Shares}

The shares which are highly profitable are measured by Equation (2). The data of three months, six months, one year and two years are utilized in Equation (2) as a target period to classify the highly profitable shares.

\section{Results Analysis}

\subsection{Analysis of Proposed Method}

Our developed system was tested by us for one year. To test the system, we invested 100000 Taka (about 980USD) in the DSE share market. We bought different shares from DSE market to test short and long term prediction methods, price sensitive and highly profitable estimation methods. During this period, we invested 20000-30000 Taka in each testing section. Most of the time, we realized a good gain. The statistics of loss and profit is provided in Table 1.

Though a good gain is observed in Table 1, a loss was realized from highly profitable prediction and a small profit was earned from price sensitive prediction. This is because, these two are greedy methods. Sometimes, such estimation gives a wrong direction to investors because that is done from fewer data. Additionally, the market in 2000 was unstable. However, the overall gain applying our proposed prediction method is $15.1 \%$, which is an attractive figure for the trade market investors. Thus, the proposed prediction method proves its efficiency.

\subsection{Description of the Components of System}

The interface for short and long term investment is depicted in Figure 1. There, one can check the shares which are promising for short and long term investment. If the user selects short term prediction option, the interface will ask for a name of a company. After taking the trade name from a user, the system computes its short term investment probability. The system, then, estimates the prospect of investment by Equation (2) and depicts the result in an interface, as shown for ACI company in Figure 2. The same is done for long term prediction option. A prediction result for long term perspective is shown in Figure 3.

Table 1. Realized gain from investment

\begin{tabular}{|c|c|c|c|c|c|}
\hline Category & $\begin{array}{l}\text { Number categories of } \\
\text { different shares }\end{array}$ & Amount in Taka & Loss in categories of Shares & Total profit & Overall gain in $\%$ \\
\hline Long term & 3 & 30000 & 1 & 6800 & \multirow{4}{*}{15.1} \\
\hline Short term & 8 & 30000 & 2 & 7800 & \\
\hline Price sensitive & 11 & 20000 & 5 & 1500 & \\
\hline Highly profitable & 12 & 20000 & 4 & -1000 & \\
\hline
\end{tabular}




\section{Investment Projection Of DSE}
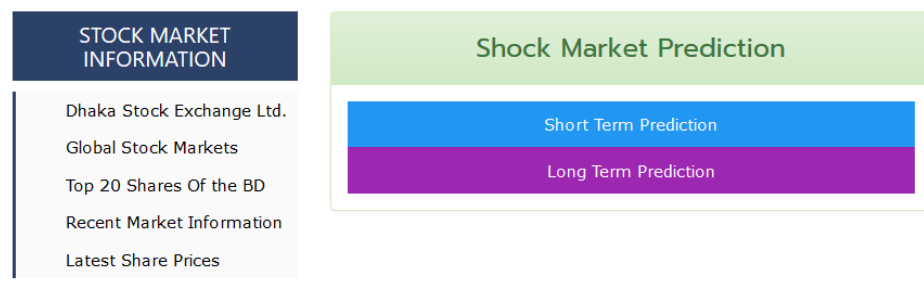

GENERAL INVESTOR GUIDELINES

General Profile of Bangladesh

Economy of Bangladesh

Performance of DSE at a glance

Share Transfer Procedure

Frequently Asked Questions

Figure 1. Short and long term prediction interface

\section{Investment Projection Of DSE}

\section{STOCK MARKET}

\section{INFORMATION}

Dhaka Stock Exchange Ltd.

Global Stock Markets

Top 20 Shares Of the BD

Recent Market Information

Latest Share Prices

\begin{tabular}{|ll|}
\hline & Long Term Prediction \\
\hline Attribute & Result \\
\hline SYMBOL & ACI \\
\hline SCORE & 0.728 \\
\hline TODAYS PRICE & 369.5 \\
\hline HIGHEST IN YEAR & 638.400 \\
\hline LOWEST IN YEAR & 0.000 \\
\hline PREDICATION & May be Profitable \\
\hline
\end{tabular}

Go Back To Homepage

Figure 2. Long term prediction result for ACI company

\section{Investment Projection Of DSE}

\section{STOCK MARKET} INFORMATION

Dhaka Stock Exchange Ltd.

Global Stock Markets

Top 20 Shares Of the BD

Recent Market Information

Latest Share Prices
Short Term Prediction

Attribute

SYMBOL

AVERAGE OPENING PRIC

HIGHEST PRICE

LOWEST PRICE

TODAYS PRICE

TODAYS OPEING PRICE

PREDICATION

\section{GENERAL INVESTOR} GUIDELINES

General Profile of Bangladesh

Economy of Bangladesh

Performance of DSE at a glance

Share Transfer Procedure

Frequently Asked Questions

Figure 3. Short term prediction result for ACI company 
Figure 4 gives a snapshot of the interface that is used for estimating price sensitive and highly profitable shares. The interface helps investors to know the price sensitive information of a single share as well as to separate a list of highly profitable shares.

The interface for price sensitive information is given in Figure 5. According to user's selection, the interface extracts related data from DSE interface; analyzes these information based on data of last one day, one month, three months or six months; and present them accordingly. It shows results in both increasing and decreasing trends as well. Figure 6 shows the results for last three month's data as a sample of an execution moment.

\section{Investment Projection Of DSE}

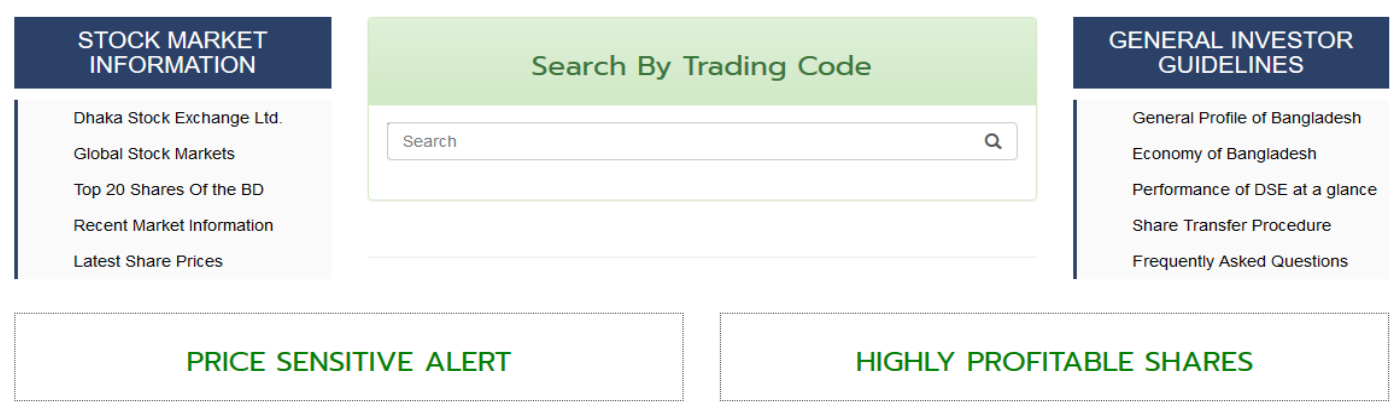

Copyright $\odot$ Department of CSE,JKKNIU,

Figure 4. Price sensitive alerting and highly profitable share measuring interface

\section{Investment Projection Of DSE}
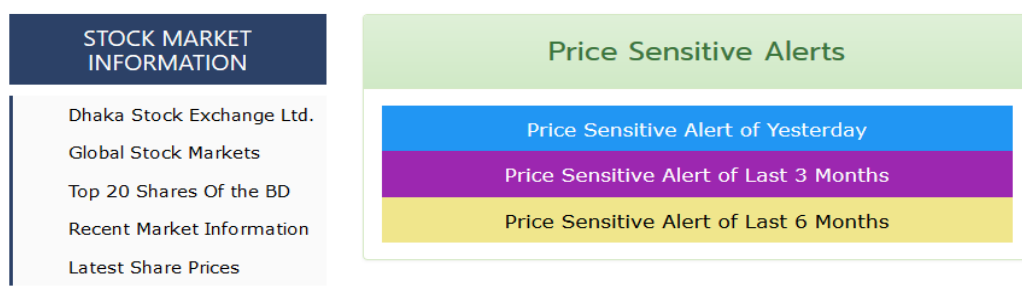

Go Back To Homepage
GENERAL INVESTOR GUIDELINES

General Profile of

Bangladesh

Economy of Bangladesh

Performance of DSE at a glance

Share Transfer Procedure

Frequently Asked Questions

Figure 5. Price sensitive alert interface 


\section{Investment Projection Of DSE}

Price Sensitive Alert of Last 3 Months

\begin{tabular}{|l|c|}
\hline & Price Sensitivity (Increasing) \\
\hline Attribute & Result \\
\hline BDAUTOCA & 76.122 \\
\hline BDLAMPS & 34.871 \\
\hline CONFIDCEM & 26.368 \\
\hline ATLASBANG & 24.345 \\
\hline ABBANK & 23.313 \\
\hline ACTIVEFINE & 14.595 \\
\hline AZIZPIPES & 13.636 \\
\hline AL-HAJTEX & 13.571 \\
\hline ARAMITCEM & 12.830 \\
\hline APEXFOOT & 11.731 \\
\hline BSCCL & 10.962 \\
\hline
\end{tabular}

\begin{tabular}{|l|l|}
\hline & Price Sensitivity (Decreasing) \\
\hline Attribute & Result \\
\hline
\end{tabular}

Figure 6. Price sensitive alert based on last three months

\section{Conclusions}

Stock market plays an important role in business and industry development of a country. People invest their money in stock market to earn a profit. However, it is not so easy to realize positive gains from such investment. Investors should be aware of their investments. At the same time, an automated system is desired to direct the investors toward profitable shares. Therefore, this proposed system would be a useful one for any investor. The system will guide them to invest their money in promising shares. If the investor use that proposed system, it is expected that they would achieve a good gain at the year end. Consequently, the system will attract more investor to invest in the market. At the same time, it will increase the stability of the stock market.

\section{References}

[1] Dhaka Stock Exchange Limited, www.dsebd.org, last visited on 26/11/2021.

[2] Sukhija, Sunita, 2014. A study regarding analyzing recessionary impact on fundamental determinants of stock prices in India share market. European Journal of Business and Management. 6(4), 161-168.

[3] Al-Shubiri, Faris Nasif, 2010. Analysis the determi- nants of market stock price movements: An empirical study of Jordanian commercial banks. International Journal of Business and Management. 5(10), 137.

[4] The New York Stock Exchange, 2021. www.NYSE. com, last visited on 26/11/2021.

[5] Sarker, M.M., Nargis, N., 2012. Identifying the critical issues of stock market: a study on Dhaka stock exchange (DSE). International Journal of Applied Research in Business Administration \& Economics. 1.03, 48-55.

[6] Uddin, Md Gazi Salah, Md Mahmudul Alam, 2007. The impacts of interest rate on stock market: empirical evidence from Dhaka Stock Exchange. South Asian Journal of Management and Sciences. 1(2), 123-132.

[7] Faruqui, Farhan, Md Habibur Rahman, 2013. Factors Influencing the Crash in the Share Market in Dhaka Stock Exchange. Research Journal of Finance and Accounting. 4(7), 139-147.

[8] Islam, S., Murshedul Arafin, Fatema Tuz Zohora, 2017. Factors affecting share price of cement industry: A study on listed cement companies of DSE. Eur. J. Business, Econ. Account 5(6), 48-66.

[9] Ali, Mohammad Bayezid, 2011. Impact of micro and macroeconomic variables on emerging stock market 
return: A case on Dhaka stock exchange (DSE). Interdisciplinary Journal of Research in Business. 1(5), 8-16.

[10] Sadat, Ahmed Raihan, Md Emran Hasan, 2019. Testing weak form of market efficiency of DSE based on random walk hypothesis model: a parametric test approach. International Journal of Accounting and Financial Reporting. 9(1), 400-413.

[11] Alam, Md, Kazi Alam, Gazi Uddin, 2007. Market depth and risk return analysis of dhaka stock exchange: an empirical test of market efficiency. ASA University Review. 1(1), 93-101.

[12] Chaity, Naznin Sultana, Sanjida Sharmin, 2012. Efficiency measures of capital market: a case of Dhaka stock exchange. International Journal of Business and Management. 7(1), 102.

[13] Choudhury, Md Ariful Haque, 2013. Stock Market Crash in 2010: An Empirical Study on Retail Investor's Perception in Bangladesh. ASA University Review. 7.1.

[14] Hossan, Mohd, 2014. Forecasting on DSE General Index and Identifying the Main Reasons Behind the Recent Market Crash. ASA University Review. 8.2.

[15] Khan, Fatima, Farhana Afrin, Mirza Arifur Rahman, 2015. Factors influencing investors' decisions in stock market investment in Bangladesh: a study on Khulna City. Journal of Finance and Accounting. 3(6), 198-204.

[16] Ghosh, Protap Kumar, Sutap Kumar Ghosh, 2015. Stock price adjustment to corporate accounting disclosure: A quantitative study on Dhaka stock exchange (DSE), Bangladesh. International Journal of Accounting and Financial Reporting. 5(2), 122-132.

[17] Uddin, Mohammed Belal, 2009. Determinants of market price of stock: A study on bank leasing and insurance companies of Bangladesh. Journal of modern Accounting and Auditing. 5(7), 1.

[18] Gosswami, Tapashi, Sanjit Kumar Saha, Mahmudul Hasan, 2018. Stock market data analysis and future stock prediction using neural network. International
Journal of Computer Science and Information Security (IJCSIS). 16.9.

[19] Rahat, M.D., Maher Mohammed Helal Uddin Choudhury, Abdur Rouf Sarker, 2008. Share market optimization: a web based system to predict share market using different kinds of economic factor. $\mathrm{PhD}$ Diss. BRAC University.

[20] Mannan, Kazi Abdul, Farhana, Dr Khandaker Mursheda, Khan Chowdhury, Torab, November 23, 2014. Rural Household Contribution to the Financial and Capital Market in Bangladesh: A Micro Level Study of Remittances from Italy. International Journal of Management Sciences and Business Research. 3(10), 112-122.

[21] Banik, Shipra, A.F.M., Khodadad Khan, Mohammad Anwer, 2014. Hybrid machine learning technique for forecasting dhaka stock market timing decisions. Computational Intelligence and Neuroscience.

[22] Dashore, Pankaj, Suresh Jain, 1973. Fuzzy rule based system to characterize the decision making process in share market. International Journal on Computer Science and Engineering. 2(6), 2010.

[23] Rony, Ismail Hossain, et al., 2019. Share market forecasting with LSTM neural network and sentimental trend prediction. PhD Diss. Brac University.

[24] Meesad, Phayung, Risul Islam Rasel, 2013. Dhaka Stock Exchange trend analysis using support vector regression. The 9th International Conference on Computing and InformationTechnology (IC2IT2013). Springer, Berlin, Heidelberg.

[25] Zahan, Arafat, Md Shohel Rana, 2020. Stock price reaction to dividend announcement: An empirical study on Dhaka stock exchange (DSE). Journal of Management, Economics, and Industrial Organization. 4(2), 1-27.

[26] Mamun, Abdullahil, Nazamul Hoque, Abdullah Mohammad Ahshanul Mamun, 2013. Stock Price Reaction to dividend announcement: the case of Bangladesh Capital market. Journal of Economics and Sustainable Development. 4(8), 89-98. 